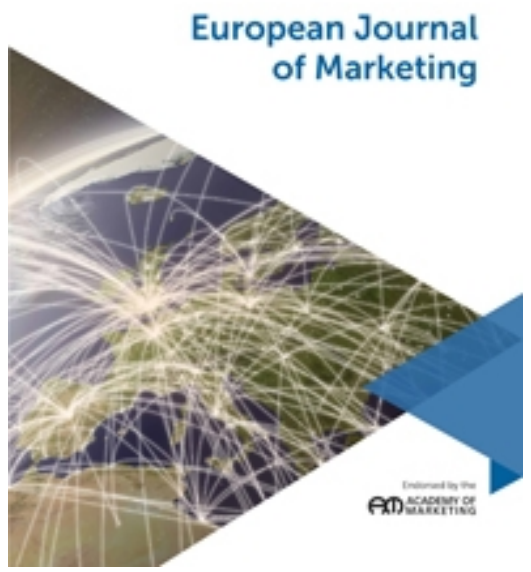

Problematizing the presentation and reception of political brands: The strategic and operational nature of the political brand alignment model

\begin{tabular}{|r|l|}
\hline Journal: & European Journal of Marketing \\
\hline Manuscript ID & EJM-03-2018-0187.R2 \\
\hline Manuscript Type: & Original Article \\
\hline Keywords: & Political branding, Political Marketing, Brand alignment \\
\hline \multicolumn{2}{|l}{} \\
\end{tabular}

SCHOLARONE ${ }^{\mathrm{m}}$

Manuscripts 


\title{
Problematizing the presentation and reception of political
}

\author{
brands: The strategic and operational nature of \\ the political brand alignment model
}

\begin{abstract}
Purpose - There are explicit calls for research devoted to how political actors present their brand to the electorate and how this is interpreted. Responding to this, the purpose of this research is to build an understanding of how political brand messages and values are received and aligned with voter expectations, which in turn shapes the consistency of a political brand.

Design/methodology/approach -Using an interpretivist perspective, this two-stage approach firstly focuses on semi-structured interviews with internal stakeholders of the UK Conservative Party and secondly uses focus group discussions with external stakeholders [voters] aged 18-24 years. Data was collected between $1^{\text {st }}$ December 2014 and $6^{\text {th }}$ May 2015.

Findings The findings suggest that the UK Conservative brand had recovered from the 'nasty party' reputation. Further, the Conservative brand was perceived as credible, trustworthy, and responsible, with positive associations of 'economic competence'. However, while the nasty party imagery has declined, the UK Conservative brand continues to face challenges particularly in terms of longstanding negative associations perceived by both internal and external markets.

Originality/Value - The brand alignment model extends current branding theory by firstly building-on an understanding of the complexities of creating brand meaning, secondly, by operationalizing differences between the brand and how it is interpreted by the electorate. Finally, identifying if internal divisions within the political party pose a threat to the consistency of the brand.
\end{abstract}

Keywords - brand alignment, political marketing, political branding.

Paper type - Research paper 


\section{Introduction}

Political brands are complex and can be applied to presidential candidates, political parties, and pressure groups. They are human and institutional, ideological and pragmatic, and there are regional variations. Political brands are dynamic, responding to a range of environmental factors, and comprise core ideas and symbolic heuristics. During the period of an election these frequently contested aspects are channelled into a manifesto that offers a promise to an electorate. Crucially, there has to be synergy between how the political brand promise is perceived externally by the electorate and internally by the party membership. The extant literature relating to building brand meaning indicates that there is broad consensus, that brand identity is an internal construct and brand image is an external construct (Harris and de Chernatony, 2001). In reality the distinctions between them are far less clearly delineated. Moreover, brand identity and brand image are seen as relational but distinct concepts that can elucidate the consistency of a brand with its functional and intangible elements. More specifically, brand identity concentrates on how brands are developed and communicated by internal stakeholders while brand image focuses on how brands are understood by consumers and/or citizens. Inconsistency between the two, which has been apparent in the two main UK political parties at times, (see for instance Ashcroft, 2005 and Radice, 1992) is referred to as the identity-image gap and this can have a detrimental effect on a brand's success in terms of trust and loyalty (Nandan, 2005). However, focusing on the binary of identity and image fails to take into consideration the co-creation of the political brand both within the internal market and by the electorate.

Indeed, the process of aligning the brand with voter perceptions is crucial when building and reinforcing a credible political brand but there is scant research that focuses on 
both. Moreover, today's political brands are comprised of complex, nuanced, intangible elements combined with personal characteristics. It is therefore timely to build an understanding of how the brand is interpreted by the electorate and their party members, and identify if or where tensions occur.

Using an interpretive approach, this paper seeks to contribute to the political marketing literature by firstly, outlining the current status of political branding research, and secondly to respond to Baines et al's (2014) call for research devoted to exploring how political actors build brand meaning and how this is understood by their target group. Hence, our aim is to focus on the incumbent UK Conservative Party brand to examine brand presentation, how it is perceived by young voters (a key target market of the Conservatives in 2015) and identify any potential misalignments that could affect the consistency of the brand offering.

\section{Political branding}

Political brands are powerful tools that can be used as a heuristic for voters. Those who have limited time and interest in politics are able to use the brand to get a feel for the ideological stance and the concomitant policy promises of the political product offering (Bale, 2008; Scammell, 2015). Political brands are complex, multi-layered entities that are often difficult to deconstruct (Lock and Harris, 1996; Phipps et al., 2010). Indeed, political brands can be considered a trinity of elements including the party, leader and policy, which presents a clearly differentiated brand from political competitors (Butler et al., 2011; Davies and Mian, 2010; O’Cass and Voola, 2011; Smith, 2008; Smith and French, 2009; Speed et al., 2015).

Effective political brands should appeal to their target audience; they should be believable and trustworthy; and act as a decision-making driver that supports strategy 
development and builds awareness in the mind of citizens (Baines and Harris, 2011; O'Cass and Voola, 2011; O’Shaughnessy and Baines, 2009). Further, political brands can build loyalty, reinforce existing beliefs, and communicate a set of brand values (Peng and Hackley, 2009; White and de Chernatony, 2002). Thus, for a political brand to succeed it needs to be "simple, aspirational and clearly differentiated from other parties" (Needham, 2005, p183) and consistent with their brand principles. In contrast, Smith and French (2009, p213) noted that "when a party becomes disunited and/or sends conflicting messages to voters, the perceived cohesion of the party brand breaks down, its credibility is lost". There have been a range of studies that have investigated political branding in different contexts (Baines et al., 2011; Davies and Mian, 2010; French and Smith 2010; Marland and Flanagan, 2014; Nord and Stromback, 2008; Phipps et al., 2010; Robinson, 2010) nevertheless there is little insight into how to capture and understand the cohesion of political brands from a party/citizen perspective (Phipps et al., 2010; Scammell, 2015).

Political brands continually attempt to create, manage or [re]position a desired identity and develop this imagery in the mind of the consumer/citizen (Baines et al., 2014). Therefore, positioning has a central place within political marketing theory as it provides insight into the political brand's product offering; responds to the wants and needs of voters; and enables strategists to create a competitive differentiation in the political market place (Wring, 2002, p181). However, understanding how political brands are positioned by political actors and how political brands are understood by citizens is often difficult to capture (Baines et al., 2014). For instance, Smith (2005) examined the positioning strategies of the three main political parties (Labour, Conservatives and the Liberal Democrats) during the 2005 UK General Election. It was found from the beginning of the campaign that all three political brands faced political 
positioning "dilemmas" (Smith, 2005, p1137) and this included the UK Conservative Party brand. The Conservative Party brand faced the internal problem of appeasing not only the previously silenced pro-European wing of the party but also the core antiEuropean constituency (Smith, 2005). In addition, the UK Conservative brand was still positioned by the party's past, they failed to develop a clear point of differentiation from political competitors, especially Labour. They were perceived as an opposition party, not credible, and a 'nasty' uncaring party for the 'rich and privileged' (Smith 2005). Furthermore, Smith (2005) concluded they had failed to produce an integrated long-term strategy and needed to develop new approaches to address the political brand's dilemmas and suggested that future research should focus on the identity/image balance of a political brand.

While extant research has tended to focus on identity or image, there are calls to take a more holistic perspective to ground future studies. This could provide a more a more complete picture of how the brand is presented at election time and how the electorate interpret the political brand (Baines et al., 2014; Needham and Smith, 2015; O'Cass and Voola, 2011). Clearly, it is crucial for political parties to conduct research to examine how the brand matches with the electorates' perception and identify where the gaps are (see for instance, Ashcroft, 2005, 2010; Gould, 1998; Radice, 1992; 1993; 1994). Internal political stakeholders such as political parties, politicians and candidates need to understand their brands and capture the associations and perceptions from the perspective of external stakeholders. They can then adapt or refine their brand to address any misalignment (Baines and Harris, 2011; O'Shaughnessy and Baines, 2009; Speed et al., 2015).

Identity and image management is a core task for political marketing and operationalizing the ideology to develop policy is crucial for political branding 
(Scammell, 2015; Smith, 2005). Brand identity can be conceptualised as the intended projection formulated and communicated by the brand's creator with the aim of attempting to establish a desired identity in the mind of the consumer (Kapferer, 2008). Further, brand identity can be used to capture the "central ideas of a brand and how the brand seeks to communicate these ideas to stakeholders" (de Chernatony, 2007, p45). In contrast, brand image can be considered as the current/immediate associations perceived and formulated in the mind of the consumer, which is often out of control of the brand's creator (Nandan, 2005) as they are also bombarded with competing messages from other sources. In addition, brand image is externally created, and manifested through unique associations and perceptions, experiences and expectations linked to physical and intangible elements of a brand (Bosch et al., 2006). Indeed, alignment between brand identity and brand image needs to be coherent, or in the words of New Labour 'on Message' which requires regular monitoring to ensure consistency between image and identity (Bronn et al., 2006; Davies and Chun, 2002). However, branding theory has also seen a shift in focus towards relationship building, foregoing short-term exchange to building longer term relationships (Fournier, 1998); building brand communities (Muniz and O'Guinn, 2001; Cova and Pace, 2001) and consumer tribes (Cova, Kozinets and Shankar, 2007). Therefore, the aim of this research is to examine the connection between the Conservative Party brand and if or how it aligns with young voters' perceptions. Secondly, we seek to establish the potential of political branding theory when considering the complex relationship between party, leader, activists, policy development and the voter.

\section{Context}

In order to contextualise this study, the UK Conservative Party was selected as it has been described as one of the oldest yet most complex political brands in the English- 
speaking world (Campbell, 2008; Lloyd, 2006). Additionally, the UK Conservative Party brand has been considered a multifaceted broad church of diverse and often contrasting values (Bale, 2011; Lee and Beech, 2009; Ross, 2015). After three election defeats [1997, 2001 and 2005] and three Conservative Party leaders, the UK Conservative Party failed in its attempt to modernise and reconnect with the wider electorate (Ashcroft, 2010; Smith, 2009). However, in December 2005, David Cameron was elected leader of the UK Conservative and Unionist Party. David Cameron vowed to be unlike previous leaders, arguing it was time to modernise and unite the party, detoxify the Conservative brand, and make the Party electable for the 2010 UK General Election (Ashcroft, 2010; Campbell, 2008; Denham and O’Hara, 2007). Following the 2010 UK General Election, David Cameron's Conservatives secured 306 seats, twenty seats short of an overall majority and this resulted in the formation of the ConservativeLiberal Democrat Coalition Government (Ashcroft 2010; Ross, 2015). However, despite David Cameron's best efforts to reposition the political brand and communicate a clear, positive, unified identity, the Conservatives continued to face challenges particularly in terms of negative stereotypical associations, internal divisions and inconsistent messages (Pich and Dean, 2015).

Nevertheless, the 2015 UK General Election served as the next milestone to build on the previous electoral success in 2010 by continuing the development and refinement of the UK Conservative Party brand and to appeal to voters beyond traditional party lines (Ashcroft, 2010; Ross, 2015). Therefore, the UK Conservative Party provides an opportunity to examine the newly positioned Conservative brand. 


\section{Methodology}

This study adopts a qualitative, interpretive approach, underpinned by grounded theory methods (Charmaz, 2006; Gioia, Corley and Hamilton, 2012; Glazer and Strauss 1967; Strauss and Corbin, 1998). Following Alvesson and Kärreman (2007) this study utilised the data or empirical material to develop "theoretical ideas through the active mobilization and problematization of existing frameworks" (Alvesson and Kärreman, 2007, p 1265). Interviews were conducted with Conservative party members together with young voters. We sought to build an understanding of their perceptions and experiences of the brand and how the Conservative brand was constructed in the minds of these participants (Berger and Luckman, 1966; Cunliffe, 2008; Schutz, 1967). We focused on building a rich understanding of how their social interactions and collective experiences affected their sensemaking of the Conservative party brand (Kvale and Brinkman, 2009; Gioia and Chittipeddi, 1991). The research was conducted in two stages, the first stage utilised conversations with Conservative party members and the second with young voters.

\section{Stage One}

Stage one focused on UK Conservative Party brand stakeholders using individual expert in-depth interviews. In-depth interviews aim to build a deep understanding of the problem by capturing associations, attitudes and experiences uncovered by using the participant's own words (Gephart, 2004; Trochim and Donnelly, 2007). Further, understanding the worldview of participants enables a richer understanding of how their reality is constructed. In-depth interviews are often seen as 'special conversations' (Rubin and Rubin, 1995, p6), flexible in terms of topic area development, spontaneous and "potentially a Pandora's box generating endlessly various and abundant data" 
(McCracken, 1988, p12). In line with Gioia et al., (2012, p 17) we recognised the participants as 'knowledge agents', as "people in organisations know what they are trying to do and can explain their thoughts and actions".

Table 1: Internal Conservative Stakeholders

\begin{tabular}{|c|c|c|c|}
\hline Code & $\begin{array}{c}\text { Element of the } \\
\text { Conservative Party }\end{array}$ & Position & Date Conducted \\
\hline Andrew & Parliamentary & Conservative Member of Parliament & $29^{\text {th }}$ January 2015 \\
\hline Milly & Professional & $\begin{array}{lll}\text { General } & \text { Election } & \text { Campaign } \\
\text { Manager } & & \end{array}$ & $30^{\text {th }}$ January 2015 \\
\hline Dianna & Parliamentary & Conservative Member of Parliament & $6^{\text {th }}$ February 2015 \\
\hline Clive & Professional & $\begin{array}{l}\text { Conservative Prospective County } \\
\text { Councillor and Researcher }\end{array}$ & $2^{\text {nd }}$ March 2015 \\
\hline Charlie & Professional & $\begin{array}{l}\text { Conservative City Councillor; } \\
\text { Leader of the Conservative Group }\end{array}$ & $27^{\text {th }}$ March 2015 \\
\hline Frances & Voluntary & $\begin{array}{l}\text { Conservative Activist; Prospective } \\
\text { Parliamentary Candidate } 2015\end{array}$ & 27 $7^{\text {th }}$ March 2015 \\
\hline Olivia & Parliamentary & $\begin{array}{l}\text { Conservative Member of the House } \\
\text { of Lords }\end{array}$ & $27^{\text {th }}$ March 2015 \\
\hline
\end{tabular}

Moreover, expert or elite interviews have also been used extensively in the political research process (Beamer, 2002) to understand the influence of experts or political leaders on the strategic development of policy or the political brand (Lees-Marshment, 2011). This study adopted a purposive sampling approach. Purposive sampling can considered an appropriate sampling technique as Stage 1 of the study had a specific purpose to explore the UK Conservative Party brand from the perspective of internal Conservative stakeholders (Alston and Bowles 2007; Zikmund 2003). Initially, the first participants were local politicians but to get a wider representation, party members were emailed via the online directory for Members of Parliament, Prospective Parliamentary candidates, local-regional campaign teams and Members of the House of Lords 
https://www.conservatives.com/OurTeam inviting twenty-five participants to take part in the study. In total seven participants accepted our invitation, seven declined, seven non-responses and four participants suggested they would be willing to take part but after the 2015 General Election. The latter four were excluded from our study as the results of the election may have influenced their views. The sample of seven internal Conservative stakeholders who were interviewed included members of the House of Commons and the House of Lords, Councillors, activists, and Prospective Parliamentary Candidates, these anonymised participants are outlined in Table 1. Elite interviews tend to be a small group of the total population (Beamer, 2002) and recruiting willing participants due to time and commitments is just one of the challenges facing researchers in political marketing research (Lilliker, 2003), particularly during an election campaign.

Internal interviews were conducted prior the 2015 UK General Election $\left(29^{\text {th }}\right.$ January 2015-27 $7^{\text {th }}$ March 2015) and each interview ranged from 60-90 minutes in total. Participants were briefed on the objectives of the study and all ethical procedures were outlined and approved by the lead researcher's institution before the commencement of the study. The interviews were recorded; the researchers took notes and wrote memos to preserve ideas often forgotten in the data collection process (Glaser, 2014; Goulding, 2002). Interviews were transcribed verbatim; read and re-read by the researchers, notes and memos were compared, then the data were coded manually into concepts, themes and aggregate dimensions. Topics in the discussion guide included their own personal values of what it means to be a Conservative, how they perceive the Conservative Party, its historical values, the role of David Cameron, and how the brand is presented to the electorate. However, there was flexibility to explore responses that emerged from the discussions and subsequent conversations were adapted accordingly. 


\section{Stage two}

Stage two concentrated on revealing how the Conservatives were perceived by young citizens, using focus group discussions. Focus group discussions were considered an appropriate data collection tool to capture opinions, feelings, and beliefs (Bloor et al., 2001; Krueger, 1994; Kvale, 1996), particularly in grounded theory (Hernandez, 2011). In addition, focus group discussions are appropriate as they aim to gather rich experiences, associations and imagery and build comprehensive understandings (Bloor et al., 2001; Bond and Ramsey, 2010; Broeckelmann, 2010; Pettigrew and Charters, 2008). In political practitioner research, focus groups have increasingly been used. For instance, Gould (1998) famously used focus groups to transform 'old' Labour into 'New' Labour - a brand untainted by the perceived undesirable associations of the 'old' Labour brand. The new Labour brand achieved unprecedented success winning three consecutive British General elections. In response to the success of the new Labour brand, and the subsequent three electoral defeats of the Conservative party, Ashcroft $(2005,2010)$ used focus groups plus polling data to identify the negative associations that constituted what Theresa May characterised as the "nasty party". These political practitioners used both focus groups and in-depth interviews to understand how political brands matched with the participants' lived experiences, which framed their worldview of politics and political brands.

A purposive sampling framework was also adopted for stage two of the study. Gorman and Clayton (2005) argue that qualitative researchers tend to select a purposive sampling framework as the aim is not to infer generalisations to the population but to gain an understanding of a particular phenomenon from the perspective of specific groups of individuals (Daymon and Holloway 2011; Gorman and Clayton 2005). In addition, a purposive sampling framework is consistent with the interpretive tradition 
and allows the researcher to be opportunistic and interview available and accessible participants within the well-defined sampling criteria (Daymon and Holloway 2011; Gorman and Clayton 2005; Zikmund 2003). Young citizens aged 18-24 years formed the sample for the external stage. This age group was explicitly selected by the UK Conservative Party as it was considered an untapped market (Ashcroft 2005; Charles 2009) following David Cameron's leadership election and was therefore viewed as an opportunity to extend the reach of the Conservative Party. These young voters were recruited by an advertisement placed in the local www.gumtree.co.uk website detailing the aims of the study, ethical issues and to highlight that age was the only prerequisite for participation as David Cameron aimed to appeal to the young electorate beyond traditional party lines (Ashcroft 2005; Ashcroft 2010). No member(s) of the UK Conservative Party were present during the data collection process nor were they involved in the research project. Therefore, stage two involved four two-hour focus group discussions with a total of twenty-five young citizens aged 18-24 years; these were conducted December 2014 - May 2015. Further, table 2 presents the participants (anonymised), their political affiliation, gender and the date the focus group was conducted. 


\begin{tabular}{|c|c|c|c|}
\hline Code & $\begin{array}{c}\text { Political } \\
\text { Identification }\end{array}$ & Gender & Date conducted \\
\hline Noah & Floating & M & $01 / 12 / 14$ \\
\hline Susan & Labour & M & $01 / 12 / 14$ \\
\hline Luke & Floating & M & $01 / 12 / 14$ \\
\hline Louise & Conservative & $\mathrm{F}$ & $01 / 12 / 14$ \\
\hline Melanie & Conservative & $\mathrm{F}$ & $01 / 12 / 14$ \\
\hline Julie & Conservative & $\mathrm{F}$ & $01 / 12 / 14$ \\
\hline Lindsay & Green Party & $\mathrm{F}$ & $01 / 12 / 14$ \\
\hline Stuart & Conservative & M & $01 / 12 / 14$ \\
\hline Clarissa & Labour & $\mathrm{F}$ & $11 / 03 / 15$ \\
\hline Nina & Green Party & $\mathrm{F}$ & $11 / 03 / 15$ \\
\hline Angela & Floating & $\mathrm{F}$ & $11 / 03 / 15$ \\
\hline David & Floating & M & $11 / 03 / 15$ \\
\hline Gareth & Labour & M & $11 / 03 / 15$ \\
\hline Nick & Floating & M & $13 / 04 / 15$ \\
\hline Mark & Conservative & M & $13 / 04 / 15$ \\
\hline Alison & Conservative & $\mathrm{F}$ & $13 / 04 / 15$ \\
\hline Daisy & Green Party & $\mathrm{F}$ & $13 / 04 / 15$ \\
\hline Martin & Green Party & M & $13 / 04 / 15$ \\
\hline Aaron & Conservative & M & $13 / 04 / 15$ \\
\hline Matthew & Conservative & M & $13 / 04 / 15$ \\
\hline Sarah & Floating & $\mathrm{F}$ & $13 / 04 / 15$ \\
\hline Brian & Conservative & $\mathrm{M}$ & $13 / 04 / 15$ \\
\hline Libby & Conservative & $\mathrm{F}$ & $13 / 04 / 15$ \\
\hline Jack & Labour & M & $13 / 04 / 15$ \\
\hline George & Floating & M & $13 / 04 / 15$ \\
\hline
\end{tabular}

Table 2: Sample for Stage Two - External Stakeholders 18-24 years

Similar to stage one, participants in stage two were briefed on the objectives of the study and all ethical procedures were outlined and approved before the commencement of the study. The discussion guide followed a process of 'cyclical development' (Gillham, 2005, p22), which in turn strengthened the validity and transparency of the analytical process. The focus groups were recorded and transcribed verbatim (Glaser, 2014; Goulding, 2002). Topics in the discussion guide covered icebreaking methods, attitudes towards the Conservative party, historical aspects, David Cameron, and any 
experience of politics but there was also flexibility to explore responses that emerged from the discussions. Two researchers conducted the interviews while one team member remained outside the data collection and initial analysis process, "to act as devil's advocate.... whose role it is to critique interpretations that might look a little too gullible" (Gioia et al, 2012).

\section{Analysis - Stage One and Stage Two}

Following transcription of the interviews, (transcripts ranged from 6000-8000 words in total) transcripts were sent to the internal stakeholders to ensure they were a true reflection of the interview (Cunliffe, 2003). This was in order to strengthen validity and transparency, as part of the external validation strategy (Warren and Karner, 2005). The researchers discussed the emerging themes and clarified any discrepancies following Butler-Kisber's (2010) course-grained/fine grained approach to data analysis. This study sought depth and insight rather than conclusive generalisations across the UK Conservative Party as a whole. The personal stories provided a rich account of their relationship with the Conservative brand, which was consistent with the philosophical assumptions of this study (Gephardt, 2004; Saunders et al., 2012, van Manen, 2014). The recordings from the focus group discussions were transcribed verbatim; and each transcript ranged from 8000-10000 words in total. Transcripts were read and re-read by the researchers who completed the data collection, notes and memos compared, then the data were coded manually, identifying first order concepts, second order themes leading to identifying the aggregate dimensions (Butler-Kisber 2010). Unlike stage one, it was not possible to send participants transcripts of stage two of the study for verification and transparency due to the complex nature of focus group discussions (Barbour, 2007; Saunders et al., 2012; Warren and Karner, 2005). The study followed a two-stage process of thematic analysis; coarse-grained followed by 
fine-grained (Butler-Kisber, 2010). The coarse-grained stage included familiarisation of all findings and identifying categories. These categories were examined to identify similarities and differences which then reduced the number of categories to a more manageable number (Gioia et al., 2012). The fine-grained second order stage was more focused and involved reviewing identified categories, analysing for hidden meaning and revisiting concepts identified from the first order, coarse-grained stage (ButlerKisber, 2010). Finally, we reduced the second order themes to aggregate dimensions.

\section{Findings}

This research focused on the Conservative Party and how the brand was constructed under the leadership of David Cameron and translated by internal stakeholders and the electorate. The core areas identified in the Conservative party manifesto were strong economy, eliminating wasteful government spending (austerity), investing in areas outside the southeast, investing in infrastructure, controlling immigration, investing in families and ensuring good schooling, protecting and improving the national health service (https://www.conservatives.com/manifesto2015). Their core groups were businesses, middle class families and broadening to those disenchanted by the new Labour leadership (Ashcroft 2010; Ross 2015). The first stage sought to provide an insight to the Conservative brand from the perspective of the Conservative Party members (see Figure 2) while the second stage analysed the young voters' perspective (see Figure 3).

\section{Conservative brand meaning - party members}

Internal stakeholders provided contrasting views regarding party leader David Cameron. Many stakeholders perceived positive characteristics including "a strong leader...passionate...charismatic" (Milly). Another, a Member of Parliament, argued 
"he's super confident, he's someone who understands the challenges we face on a daily basis and he delivers on those problems... and he has a plan and his plan works" (Dianna). However, several internal stakeholders argued that David Cameron was a weak figurehead, elitist, more populist than authoritarian and unreflective (Andrew; Charlie; Olivia).

The Conservative brand continued to be seen as a broad church united by core Conservative values such as strong defence, low taxes, strong on law and order, belief in freedom, supporter of decentralisation, low taxes and belief in strong economic prudence. It was also accepted that there was some tension within this broad church and although Conservative values were viewed as 'timeless', there was significant contestation that values can be frequently be internally divisive. For example, a Member of Parliament argued, “I don't agree with everything...we are a broad church and the Conservatives can accommodate that" (Dianna). 
Figure 2. Conservative Brand meaning - party members

While Conservative values "are timeless and never change" (Andrew) it is in fact the policies linked to these values that change and cause debate within the party. For example, the majority of internal stakeholders were confident that their party "tackled the economy" (Olivia) which created a strong competitive advantage in the minds of voters in terms of economic competence. Many of the narratives supported rather than contradicted the Conservative message, which in turn clarified the Conservative brand. However, a number of participants were rather negative which revealed a not insignificant self-interest. For example, one Member of Parliament revealed a pessimistic view that the party would not "win a majority" and it did not matter if the party returned to opposition as the focus was their constituency and raising the profile of their constituents (Andrew). Indeed, they reflected that a different leader would make 
a positive change and increase the chances of securing a majority at the election (Olivia).

Several internal stakeholders argued that the physical communication tools such as campaign leaflets, posters, and weekly newsletters, use of party logo and consistency of message had strengthened in professionalism compared with the 2010 General Election. A Member of Parliament revealed that there was much more collaboration with Conservative Central Head Office (CCHQ) in developing communication tools to ensure a blended central/local message to constituents that strengthened overall consistency.

The idea of a central-led approach was highlighted by another Member of Parliament. For example, "the [central] party produces an essential literature pack where it has all the same branding, but the content is yours locally" (Andrew). This central-led approach was also confirmed by an Election Campaign Manager at CCHQ. CCHQ is responsible for proof reading and signing off all constituency communication tools such as leaflets before distribution. For example, the campaign manager stressed

"candidates are free to use a corporate branding pack such as templates for posters, leaflets etc. However, candidates are entitled to use their own colours, logos, policies or pledges as long as it was signed off by the CCHQ team for quality control and consistency of message", (Milly).

Despite participants revealing a consistent central-led approach to communication tools several stakeholders revealed tension and a degree of rebellion when discussing this approach. For example, the leader of the Conservative group of a city council disliked this centralised approach and sent out locally designed communication tools "because it works for us...we don't intend to stop" (Charlie). A Member of Parliament also revealed that "on occasion" they had sent off locally produced material unsanctioned 
by CCHQ. CCHQ are "sometimes not happy with my literature that I have put out there, but I haven't changed it as a result" (Andrew).

Tensions within the party extended to the internal relationship between central party and local party. This may be a result of the campaign strategies adopted by CCHQ. A campaign manager at $\mathrm{CCHQ}$ explained that Parliamentary candidates/constituencies were ranked in accordance to target/marginal and safe seats. For example, competitor Parliamentary seats with a difference of $0-8000$ votes were considered 'target/marginal seats' which were considered crucial in securing an overall majority (Milly). Safe seats were considered constituencies with $8000+$ votes (Milly). Depending on the type of constituency [safe or marginal], this would have an impact on the monetary support, guidance, freedom and personal attention provided by CCHQ and the central party.

The internal stakeholders believed the UK Conservative Party represented an inclusive party with something to offer everyone in society. One Member of Parliament revealed, “we shouldn't...have a one sort of person in mind as we should be able to connect with every voter" (Dianna). However, several participants expanded on this and argued their party attracted aspirational, hardworking voters and people who believed in core Conservative values. For example, a Member of Parliament argued

"we are for aspiration and for the people that want to work and do better for themselves...there will always be a strong market for conservative values and Tony Blair realised that if he was going to win an election he had to sound like a Conservative because we are as a country Conservative", (Andrew).

However, questions continued to be raised about whether the Conservative Party was perceived to represent the rich and privileged in society. 


\section{Conservative Brand - young voters}

The second stage of our study focused on the young voters' sensemaking of the Conservative party (Figure 3). Many external stakeholders including floating voters presented positive associations of David Cameron, such as engaging, family orientated (Stuart), well educated (Luke), Prime Ministerial (Noah), passionate (George), charismatic (David) and a strong leader (Daisy). In contrast, several voters including floating and Conservative voters highlighted negative associations such as smarmy (Clarissa), untruthful and sly (Louise), sleazy salesman (Julie), privileged (Aaron; Libby). Crucially he was considered more positive and Prime Ministerial compared with his key political Labour rival Ed Miliband who was considered weak, "can't defend himself” (Luke), disengaging, un-Prime Ministerial, unprofessional, lacking passion and seen as a 'wet-wipe' (David; Nick) by many participants including floating voters. 
"If you sat him [Ed Miliband] down in a room with serious politicians he would get laughed out of there - he is a joke...I would rather David Cameron run our country and I'm not a Conservative at all", (Aaron).

The discussions revealed that young voters of all political affiliation projected some understanding of Conservative Party policy and values. For example, it was believed the Conservative Party was tough on immigration, less reliant on the state, strong on 
the economy, reducing the deficit, supporter of business, nuclear family friendly, lower taxes and in favour of privatisation. A floating voter suggested that "it seems they are concentrating on what's best for the UK and moving forward and being economically strong" (Noah), while a Conservative supporting participant believed "they helped us get out of recession" (Melanie). Even a Green Party supporter argued Conservative values and policies support "people who have worked really hard" (Nina) and a floating voter believed "they'll lower the tax you pay" (Nick). Regardless of this, a number of participants believed that the Conservative Party had placed "less emphasis on their values and more emphasis on like what they have actually done" (Aaron) in office from 2010-2015 in contrast to Ed Miliband's Labour Party. For example, a Conservative supporter revealed "the Conservatives are coming out with facts like 'we've done this and if you vote for us we'll do that' but Labour are sort of like coming up with things to attack them with" (Alison).

In terms of the Conservative Party logo, the majority of participants revealed stronger recognition of the blue and green oak tree logo compared with the competitors. However, many participants failed to provide meaning associated with the logo or projected negative associations. For example, the logo seemed "weird" (Louise), "child-like" (Alison) and "unclear" (Gareth). Nevertheless, several participants including Conservative and floating voters found the logo appealing in terms of its aesthetics and perceived meaning. For example,

"I understand the tree. I imagine it's an oak tree about strength and continued growth", (Mark)

"I quite like the Green Party and the Conservative Party logo because you associate green with positive", (Angela). 
However, the majority of participants had little connection with the UK Conservative party and since the 2010 General Election had had direct experience of a Conservativeled Coalition government. This offered participants a taste of what they could expect from the Conservative brand if re-elected and this offered some differentiation compared to competitors. Participants discussed indirect experiences of the Conservative brand ranging from stories or narratives passed down through family members about previous Conservative governments. For example, "Margaret Thatcher is not allowed to be mentioned in the house..." (Clarissa). Similarly, "I think Thatcher is like the Conservative Party image in people's heads" (Louise), "Thatcher went for privatisation of everything and that's just thinking about money...made half the north of England unemployed” (Susan), “... she closed the mines” (Stuart).

Young participants of all political affiliations including Conservative and floating voters continued to hold a negative view of the Conservative brand. They were considered "party of the rich" (Lindsay), for "toffs" (Louise), "middle-class" (Julie; Stuart; Martin), "posh people” (Luke; Libby) and just represented businesses and money-orientated individuals. But alongside the negative perceptions and associations, the Conservatives hold their reputation as the Party of strong economic policies and

\footnotetext{
“They don't make popular decisions but they've managed to pull us out of recession. Admittedly they'll privatise things but I think they will run a harder line", (Mark).
}

\section{Discussion}

This study has responded to calls for research devoted to providing an holistic analysis of how political actors create and manage political brand meaning and how young voters make sense of the brand (Baines et al. 2014; Needham and Smith, 2015; O'Cass 
and Voola, 2011). Moreover, we sought to understand if and how the Conservative broad church party members accepted and engaged with the Cameron Conservative brand. Hence, our study sought to understand the challenges of creating and managing brand meaning when seeking to appeal to a range of audiences.

The Conservative Party brand was associated with perceptions of economic competence, a characteristic that it had lost in 1993. Therefore, while some internal stakeholders disagreed with the leadership, they did see them as electable and therefore reluctantly appealing. However, compared to political rivals, namely Ed Miliband's Labour party, the Conservatives were perceived as a better option although not necessarily a positive one. Nevertheless, despite some negative associations, David Cameron was believed to possess qualities analogous to a political leadership and for Bale (2011) able to lead the Conservatives convincingly back to the Centre ground. Significantly, this research revealed that the broad church divided into two main groups reflecting the current characterisation of one nation Tory pro remain, and the more right wing group of BREXIT supporters (Anand and Salter, 2016). However, in the 2015 UK General Election, the Conservatives projected a political brand that was electable despite some differences in perception, values, experiences. Cameron was seen to be a more credible and persuasive leader in comparison to Ed Milliband, and the party members were largely supportive although some maintained their sense of independence at a local level. In addition, this study revealed that the Conservatives had started to regain their reputation for economic responsibility, tradition and a Prime ministerial leader. Nevertheless, the Conservatives were finding it difficult to dislodge the 'nasty party' image despite the uncertainties of Labour which appeared to partially neutralise some of the party of the rich and privileged imagery. This demonstrates the multi-layered nature of political brands and the challenges of deconstructing these 
complex entities (Lock and Harris, 1996; Phipps et al., 2010). Nevertheless, the Conservatives in part were seen as a more persuasive political brand as it was perceived as stronger and more appealing than the alternatives but supported by the fact that the electoral system also favours the Conservative party (Curtice, 2015). Therefore, although there were a number of factors that did enhance the chances of re-election, the values espoused through the Conservative brand were largely consistent and persuasive. Consistent brand values can build loyalty, reinforce existing beliefs and provide a means of identification and differentiation (Needham 2005; Peng and Hackley, 2009; White and de Chernatony, 2002). Thus, synergy between sense making and sense taking (Gioia and Chittipeddi, 1991) enhances the political brand's credibility and authenticity, which in turn increases the chances of electoral success (Smith and French 2009).

Extant research has articulated the difficulty of capturing how political brands are positioned by political actors (Baines et al. 2014; O'Shaughnessy and Baines 2009; Smith 2005; Smith and Saunders 1990). However, although existing research calls for future research to adopt a more holistic perspective (Baines et al., 2014; Needham and Smith, 2015; O'Cass and Voola, 2011), there are limited operational mechanisms designed to monitor how a political brand is projected and interpreted by their target audience. The brand alignment framework (figure 4) seeks to address the gap in the literature The framework is a mechanism that identifies how the tacit and explicit values (Fournier, Breazeale and Avery, 2015) of a political brand can be understood through meaning creation and brand projection while having insight into how the brand is understood and interpreted by the target audience. 


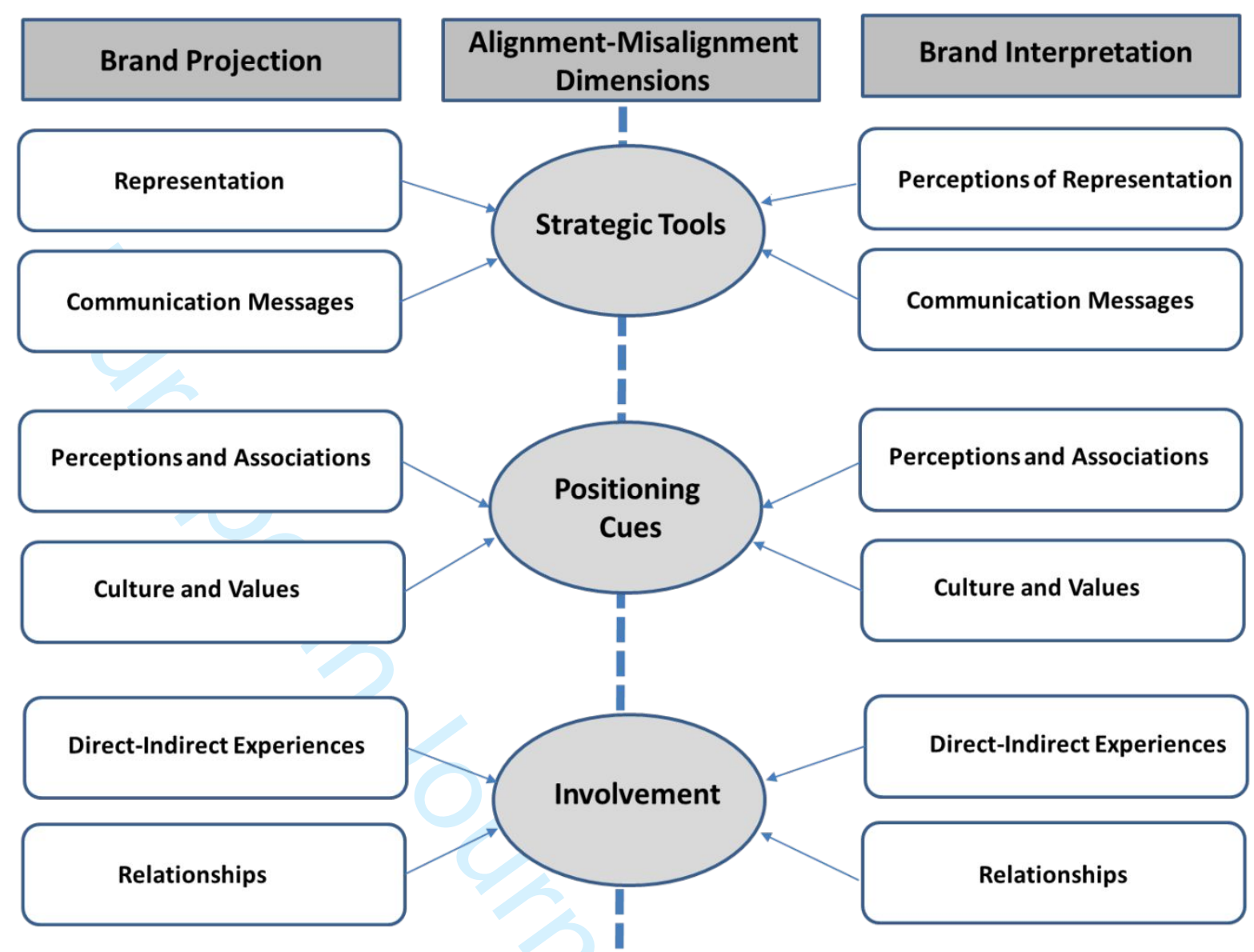

Figure 4. The Brand Alignment Framework

Thus, this framework can aid political strategists in identifying any alignment/misalignment with how the brand is presented to the target audience and how it is received. As we move towards an understanding of the importance of culture in brand building (Holt, 2004; Kapferer, 2008) it is crucial to understand the culture and values of the target audience and identify synergy between the political brand culture and values. Moreover, as electoral participation is declining (Sloam and Henn, 2018) encouraging engagement and involvement can be determined by the voters' experiences and relationship with the political party. 
Table 4: Dimensions of the Brand Alignment Framework

\begin{tabular}{|c|c|c|c|c|}
\hline Dimension & \begin{tabular}{|c|} 
Internal Brand Projection \\
How the brand is presented
\end{tabular} & $\begin{array}{c}\text { Internal Brand Interpretation } \\
\text { How the brand is internally } \\
\text { perceived }\end{array}$ & $\begin{array}{c}\text { External Brand } \\
\text { Interpretation } \\
\text { How the brand is interpreted } \\
\text { by the electorate }\end{array}$ & $\begin{array}{c}\text { External Potential Brand } \\
\text { Projection } \\
\text { How the brand should be } \\
\text { presented }\end{array}$ \\
\hline $\begin{array}{c}\text { Strategic } \\
\text { Tools }\end{array}$ & $\begin{array}{l}\text { The strategic tools dimension focuses on } \\
\text { the communicative tools-messages used } \\
\text { by political brands such as online and } \\
\text { offline tools, Itangible and intangible } \\
\text { symbols such as logo, messages, } \\
\text { mission statement, vision. In addition, } \\
\text { this dimension also considers who the } \\
\text { political brand represents from the } \\
\text { perspective of internal stakeholders. This } \\
\text { may be similar or different from the } \\
\text { actual target market The strategic tools } \\
\text { dimension identifies how the brand is } \\
\text { presented in terms of its intended } \\
\text { identity. }\end{array}$ & $\begin{array}{l}\text { This dimension may reveal } \\
\text { internal tensions or } \\
\text { inconsistencies between the } \\
\text { intended identity and perceived } \\
\text { image in relation to strategic } \\
\text { tools used by the political brand. } \\
\text { Political brands should ensure } \\
\text { degree of alignment. }\end{array}$ & $\begin{array}{l}\text { The strategic tools dimension } \\
\text { identifies how the brand is } \\
\text { interpreted by the electorate in } \\
\text { relation to external image. The } \\
\text { strategic tools dimension focuses } \\
\text { on the awareness and } \\
\text { understanding of the } \\
\text { communicative tools-messages } \\
\text { and symbols used by the political } \\
\text { brand. In addition, this dimension } \\
\text { also considers the perceptions of } \\
\text { who the political brand represents } \\
\text { and/or target market from the } \\
\text { perspective of the electorate. }\end{array}$ & $\begin{array}{l}\text { Once the internal identity, internal } \\
\text { image and external image have been } \\
\text { deconstructed, the final step turns to } \\
\text { researching how the brand should be } \\
\text { presented. Feedback and reflection } \\
\text { will help political brands select } \\
\text { appropriate and effective strategic } \\
\text { tools and practices to develop the } \\
\text { political brand. }\end{array}$ \\
\hline $\begin{array}{l}\text { Positioning } \\
\text { Cues }\end{array}$ & $\begin{array}{l}\text { The positioning cues dimension includes, } \\
\text { perceptions and associations of the } \\
\text { political brand, and its values and } \\
\text { heritage. This dimension also includes } \\
\text { personality characteristics of the } \\
\text { party/brand leader expectations of how } \\
\text { the political brand will perform in terms } \\
\text { of policy and ideology. }\end{array}$ & $\begin{array}{l}\text { Internal stakeholders may have a } \\
\text { coherent or incoherent } \\
\text { understanding of the positioning } \\
\text { cues used to develop an } \\
\text { intentional identity Political } \\
\text { brands should strive for } \\
\text { consistency between intentional } \\
\text { identity and understand internal } \\
\text { image. }\end{array}$ & $\begin{array}{l}\text { This dimension focuses on how } \\
\text { the positioning cues such as } \\
\text { perceptions \& associations, } \\
\text { personal characteristics of the } \\
\text { political brand } \\
\text { leader/politician, expectations } \\
\text { all interpreted and understood } \\
\text { by the electorate. }\end{array}$ & $\begin{array}{l}\text { Political brands can reflect on the } \\
\text { identity and image and manage } \\
\text { positioning cues to improve the } \\
\text { political brand. For example, } \\
\text { clear articulated values should } \\
\text { emphasise differentiation from } \\
\text { other competitor parties. } \\
\text { Positioning cues can also offer } \\
\text { rationale for identification. }\end{array}$ \\
\hline Involvement & $\begin{array}{l}\text { This involvement dimension includes the } \\
\text { direct and indirect experiences [such as } \\
\text { past accomplishments, successes, } \\
\text { expertise or skills] used by the political } \\
\text { brand to develop an intentional identity. } \\
\text { For example, how the history, previous } \\
\text { leadership, current leadership and policy } \\
\text { preferences are positioned to manage a } \\
\text { desired identity. The involvement } \\
\text { dimension also acknowledges the key } \\
\text { internal and external relationships that } \\
\text { support the management of the political } \\
\text { brand. }\end{array}$ & $\begin{array}{l}\text { The involvement dimension also } \\
\text { considers internal stakeholders } \\
\text { perceptions of the direct and } \\
\text { indirect experiences and their } \\
\text { impact on the political brand } \\
\text { identity. The involvement } \\
\text { dimension also consider the } \\
\text { relationships between the } \\
\text { internal market and central } \\
\text { party/brand, key stakeholders } \\
\text { such as competitors, media and } \\
\text { supporters and electorate. } \\
\text { Tensions within involvement } \\
\text { can impact the synergy of the } \\
\text { brand identity. }\end{array}$ & $\begin{array}{l}\text { This involvement dimension } \\
\text { includes the direct and indirect } \\
\text { experiences [such as past } \\
\text { accomplishments, successes, } \\
\text { expertise or skills] interpreted } \\
\text { by the electorate [brand } \\
\text { image]. The involvement } \\
\text { dimension also considers the } \\
\text { relationship between citizens } \\
\text { and the political brand. }\end{array}$ & $\begin{array}{l}\text { Political brands can reflect on the } \\
\text { involvement dimension and } \\
\text { consider how to build on } \\
\text { opportunities of positive } \\
\text { experiences and existing } \\
\text { relationships to develop its } \\
\text { desired position. Identified } \\
\text { tensions, negativities and } \\
\text { misalignments can be } \\
\text { refined/addressed to build a } \\
\text { coherent identity-image. }\end{array}$ \\
\hline
\end{tabular}


Table 4 outlines the four dimensions that underpin the brand alignment framework. The first dimension focuses on how the brand is presented (brand meaning) by internal stakeholders which are constructed via the strategic tools, positioning cues and involvement signals. The second dimension focuses on how the brand is perceived by party members, as this may be consistent or inconsistent from the intended presentation, which in turn can reveal harmony or tensions within the brand. While this study revealed the Conservative Party still fits broadly into two groups, which reflect the BREXIT divisions (Anand and Salter, 2016), tension is also evident between some local MPs and party activists with the Conservative Central Office. Indeed, some indicated sympathy for Nigel Farage and UKIP, which illustrates the increasing polarisation of the broad church Conservative party (Kentish, 2018). This illustrates that party members needs careful monitoring as well as the electorate. The dilemma of accommodating the increasingly diverse values within a party and seeking to appeal to the electorate with a consistent brand, is the most challenging aspect of election campaigning. New Labour under Tony Blair's leadership (supported by Peter Mandelson and Alistair Campbell) ensured all communications were on-message and David Cameron's Conservative party sought to do the same. Brand consistency is crucial if the party is to succeed at election times.

The third dimension captures how the brand is interpreted by the electorate and supported by the strategic tools, positioning cues and involvement signals. This will uncover alignment-misalignment between brand projection and brand interpretation. Identified alignment can be maintained and managed to ensure continued coherent messages and cohesion of the brand. For example, this study revealed some consistency with Conservative brand values and policy areas such as tough on immigration and supportive of decentralisation but also the implicit notions of tradition, heritage and 
experience, which are core values of the Conservative brand. Thus, misalignment can be addressed by the creation of a strategic plan to develop consistent positioning, ensuring party members are on-message and connect with the electorate. In addition, misalignment can be managed in conjunction with the fourth dimension, which considers how the brand should be presented. This final dimension supports the development and refinement of the brand by working with the electorate to reflect and provide feedback on the current and potential strategic tools, positioning cues and involvement signals to improve brand alignment, appeal and authenticity.

Therefore, brands should be routinely examined to understand the current position in the mind of party members and the electorate to manage any potential misalignment (Bronn et al. 2006; Davies and Chun 2002; de Chernatony 2007; Wring 2002). This is particularly crucial for political parties to examine how the brand matches with the electorates' perceptions and identify any misalignment (see for instance, Ashcroft, 2005, 2010; Gould, 1998; Radice, 1992; 1993; 1994). Political parties, politicians and candidates need to understand how their brands match the electorates' associations and perceptions. They can then adapt or refine their brand to address any misalignment (Baines and Harris, 2011; O’Shaughnessy and Baines, 2009; Speed et al., 2015). The brand alignment framework illustrates the complexity of political brand management as political brands need to be mindful of their party members' values and expectations and their target audience within the electorate as a whole.

\section{Conclusion}

The aims of this research were to respond to Baines et al.'s (2014) call for research devoted to examining how political actors present their brand and how this is understood by the electorate. Using an holistic approach this study reveals how the 
Conservative party sought to co-create the Conservative brand with their internal market and how the brand meaning was in part reluctantly accepted and then presented to the electorate. Secondly, we wanted to understand how young voters made sense of the brand and if or how they engaged with it (Baines et al. 2014; Needham and Smith, 2015; O’Cass and Voola, 2011).

The brand alignment model provides a mechanism to build and monitor the positioning of political brand that is imperative in the contemporary political environment (Baines et al. 2014; O'Shaughnessy and Baines 2009; Smith 2005; Smith and Saunders 1990). This enables the internally produced brand promise to be presented to the electorate in a form that creates synergy and responds to their cultural values and attitudes, and thus is more likely to provide encouragement to engage and vote for the party.

The brand alignment framework extends current branding theory as it incorporates both internal and external perceptions. It can also detect any perceptual differences between leadership and those of the internal market. This study exposed significant tension between the centre and local politicians who continued to present their own version of the Conservative party; it also revealed the polarisation of the broad church into two factions. This has been further factionalised following the BREXIT referendum and subsequent plans to leave the European Union. The brand alignment framework can help to elucidate where tensions may emerge: whether there is a perception of an erosion of cultural or political values; whether a leader is perceived as capable/incapable of delivering an election victory; and whether the policy and communications strategy are appropriate.

As Scammell (2015:15) argued, "the test of any model is how well it applies to the real world, what value it adds to existing models of analysis". This study has demonstrated 
how the brand alignment framework can help to illuminate components of the political brand and how it is interpreted by the electorate. The increasing polarisation in politics has made this a vital area for study as we see need to understand if, how or why citizens are persuaded by a more polarised brand message. There are also social media issues for the political brand which can distort the carefully constructed brand and turn it to what Thompson et al., (2005) describes as a Döppelganger brand. There are opportunities to evaluate and operationalize this framework in other political contexts. Indeed, the political marketing literature needs more studies in contexts where the negotiations and interpretations between political brand sensemaking and sensetaking (Gioia and Chittipeddi 1991) take place within and beyond Europe. Our research makes a clear contribution towards the understanding of the development, communication and protection of a political brand. Of particular importance is the need to ensure that the internal brand is consistent with that of the externally presented brand and that all members of the political party should be working within clearly defined parameters of what that brand is supposed to be. 


\section{References}

Alston, M. and Bowles, W. (2007), Research for Social Workers: An Introduction to Methods, London: Routledge.

Alvesson, M. and Kärreman, D. (2007), "Constructing Mystery: Empirical Matters in Theory Development", The Academy of Management Review, Vol. 32 No 4, pp. 12651281.

Anand, M. and Salter, J.P. (2016), "Brexit: initial reflections", International Affairs, Vol. 92 No. 6, pp. 1297-1318.

Ashcroft, M.A. (2005), Smell the Coffee: A wake-up call for the Conservative Party, Great Britain: CGI Europe.

Ashcroft, M.A. (2010), Minority Verdict: The Conservative Party, the voters and the 2010 election, London: Biteback Publishing Ltd.

Baines, P. Crawford, I. O'Shaughnessy, N. Worcester, R. and Mortimore, R. (2014), "Positioning in political marketing: How semiotic analysis adds value to traditional survey approaches", Journal of Marketing Management, Vol. 30 No. 1-2, pp. 172-200.

Baines, P. and Harris, P. (2011), "Marketing in the 2010 British General Election: perspectives, prospect, and practice”, Journal of Marketing Management, Vol. 27 No. 7-8, pp. 647-655.

Baines, P. Macdonald, E.K. Wilson, H. and Blades, F. (2011), "Measuring communication channel experiences and their influence in voting in the 2010 British General Election”, Journal of Marketing Management, Vol. 27 No. 7-8, pp. 691-717.

Bale, T. (2011), The Conservative Party from Thatcher to Cameron. Cambridge: Polity Press.

Bale, T. (2008), “A Bit Less Bunny-Hugging and a Bit More Bunny-Boiling? Qualifying Conservative Party Change under David Cameron", British Politics, Vol. 3 No.3, pp. 270-299.

Barbour, R. (2007), Doing Focus Groups, London: Sage Publications Ltd.

Beamer, G. (2002), "Elite Interviews and State Politics Research", State Politics \& Policy Quarterly, Vol. 2 No.1, pp. 86-96.

Berger, P. and Luckmann, T. (1966), The Social Construction of reality: A Treatise in the Sociology of Knowledge. Harmondsworth, Penguin.

Bloor, M. Frankland, J. Thomas, M. and Robson, K. (2001), Focus Groups in Social Research, London: Sage Publications Ltd. 
Bond, D. and Ramsey, E. (2010), "The role of information and communication technologies in using projective techniques as survey tools to meet the challenges of bounded rationality", Qualitative Market Research: An International Journal, Vol. 13 No. 4, pp. 430-440.

Bosch, J. Venter, E. Han, Y. and Boshoff, C. (2006), "The Impact of brand identity on the perceived brand image of a merged higher education institution: Part one", Management Dynamics, Vol. 15 No. 2, pp. 10-30.

Broeckelmann, P. (2010), "Exploring consumers' reactions towards innovative mobile services", Qualitative Market Research: An International Journal, Vol. 13 No. 4, pp. 414-429.

Bronn, P.S. Engell, A. and Martinsen, H. (2006), "A Reflective Approach to Uncovering Actual Identity”, European Journal of Marketing, Vol. 40 No.7-8, pp. 886901.

Butler-Kisber, L. (2010), Qualitative Inquiry: Thematic, Narrative and Arts-Informed Perspectives, London: Sage Publications Ltd.

Butler, P. Collins, N. and Speed, R. (2011), "The Europeanisation of the British political marketplace", Journal of Marketing Management, Vol. 27 No. 7-8, pp. 675690.

Campbell, J. (2008), In defense of David Cameron: How the Tories have gotten past soul searching in opposition. Review - Institute of Public Affairs, 60 No.1, 33-36. Retrieved from http://www.ipa.org.au/library/publication/1210833688_document_601 campbell.pdf

Charles, G. (2009), "Conservative Party targets young voters with Spotify ad campaign”, PRWeek (Online). (Accessed 18 $8^{\text {th }}$ October 2009). Available from World Wide Web: http://www.prweek.com/uk/news/946201/Conservative-Party-targetsyounger-voters-spotify-ad-campaign/?DCMP=ILC-SEARCH.

Charmaz, K. (2006), Constructing Grounded Theory: A Practical Guide through Qualitative Analysis. London: Sage.

Conservative and Unionist Party. (2014), Conservatives Our Team, (Accessed $18^{\text {th }}$ December 2014). https://www.conservatives.com/OurTeam

Creswell, J.W. (2007), Qualitative Inquiry and Research Design, London: Sage Publications Ltd.

Cunliffe, A. L. (2008), “Orientations to social constructionism: Relationally responsive social constructionism and its implications for knowledge and learning", Management Learning, Vol. 39 No. 2, pp. 123-139. 
Cunliffe, A. (2003), "Reflexive Inquiry in Organisational Research: Questions and Possibilities”, Human Relations, Vol. 56 No. 8, pp. 983-1003.

Curtice, J. (2015), “A Return to Normality? How the Electoral System Operated", Parliamentary Affairs, Vol 68 No. 1, pp. 25-40.

Dahlen, M. Lange, F. and Smith, T. (2010), Marketing Communications: A Brand Narrative Approach, West Sussex: John Wiley and Sons Ltd.

Davies, G. and Chun, R. (2002), "Gaps Between the Internal and External Perceptions of the Corporate Brand”, Corporate Reputation Review, Vol. 5 No. 2-3, pp. 144-158.

Davies, G. and Mian, T. (2010), "The reputation of the party leader and the party being led". European Journal of Marketing, Vol. 44 No.3-4, pp. 331-350.

Daymon and Holloway (2011), Qualitative Research Methods in Public Relations and Marketing Communications, New York: Routledge.

De Chernatony, L. (2007), From Brand Vision to Brand Evaluation. Oxford: Butterworth-Heinemann.

Denham, A., and O'Hara, K. (2007), “The Three 'Mantras': 'Modernisation' and the Conservative Party 1945-2005”, British Politics, Vol. 2 No. 2, pp. 167-190. DOI: 10.1057/palgrave.bp.4200057.

Fournier, S. Breazeale, M. and Avery, J. (2015), Strong Brands, Strong Relationships, Abingdon, Oxon: Routledge.

French, A. and Smith, G. (2010), "Measuring political brand equity: a consumer oriented approach”, European Journal of Marketing, Vol. 44 No. 3-4, pp. 460-477.

Gephart, R. (2004), "Qualitative Research and the Academy of Management Journal", Academy of Management Journal, Vol. 47 No. 4, pp. 454-462.

Gillham, B. (2005), Research Interviewing: the range of techniques, Berkshire England: Open University Press.

Gioia, D. A. and Chittipeddi, K. (1991), "Sensemaking and Sensegiving in Strategic Change Initiation”, Strategic Management Journal, Vol. 12 No. 6, pp. 433-448.

Gioia, D. A. Corley, K. G. and Hamilton, A. L. (2012), "Seeking Qualitative Rigor in Inductive Research: Notes on the Gioia Methodology", Organisational Research Methods, Vol. 16 No. 1, pp. 15-31.

Glaser, B. G. (2014), Memoing: A vital Grounded Theory Procedure. Mill Valley, CA: Sociology Press.

Glaser, B. G. and Strauss, A. (2000), The discovery of grounded theory: Strategies for qualitative research. Abingdon, Oxon: Routledge 
Glaser, B. G. and Strauss, A. (1967), The discovery of grounded theory: Strategies for qualitative research. Abingdon, Oxon: Routledge

Gorman and Clayton (2005), Qualitative Research for the Information Professional, London: Facet Publishing.

Gould, P. (1998), The Unfinished Revolution: How the modernisers saved the Labour Party. London: Little, Brown and Company.

Goulding, C. (2002), Grounded Theory: A Practical Guide for Management, Business and Market Researchers. London: Sage.

Gurau, C. and Ayadi, N. (2011), "Political communication management", Journal of Communication Management, Vol. 15 No. 1, pp. 5-22.

Harris, F. and de Chernatony, L. (2001), "Corporate Branding and Corporate Brand Performance”, European Journal of Marketing, Vol. 35 No. 3-4, pp. 441-456.

Kapferer, J. N. (2008), The New Strategic Brand Management: creating and sustaining brand equity long term. London: Kogan Page.

Kentish, B. (2018), "Battle lines drawn in Tory civil war as former BREXIT minister warns May of "catastrophic split". Independent (Online). (Accessed 10 ${ }^{\text {th }}$ September 2018). Available from https://www.independent.co.uk/news/uk/politics/conservativeparty-split-theresa-may-chequers-brexit-steve-baker-conference-a8530126.html.

Krueger, R.A. (1994), Focus Groups: A Practical Guide for Applied Research, London: Sage Publications Ltd.

Kvale, S. (1996), An Introduction to Qualitative Research Interviewing, London: Sage Publications Ltd.

Kvale, S. and Brinkmann S. (2009), Interviews: Learning the Craft of Qualitative Research Interviewing. London: Sage.

Lee, S. and Beech, M. (2009), The Conservatives Under David Cameron: Built to Last? Hampshire: Palgrave Macmillan.

Lees-Marshment, J. (2009), Political Marketing: Principles and Applications, Abingdon Oxon: Routledge.

Lillieker, D. G. (2003), "Interviewing the Political Elite: Navigating a Potential Minefield”, Politics, Vol 23 No. 3, pp. 207-214.

Lincoln, Y. S. and Guba, E. G, (1985), Naturalistic inquiry. Newbury Park, CA: Sage.

Lloyd, J. (2006), The 2005 General Election and the emergence of the negative brand. In Lilleker, D. G. Jackson, N. A., \& Scullion, R. The Marketing of Political Parties: 
Political Marketing at the 2005 British General Election (pp59-80). Manchester: Manchester University Press.

Lock, A. and Harris, P. (1996), "Political Marketing - vive la difference!" European Journal of Marketing, Vol. 30 No. 10-11, pp. 21-31.

Marland, A. and Flanagan, T. (2014), "Brand New Party: Political Branding and the Conservative Party of Canada", Canadian Journal of Political science, Vol. 46 No.4, pp. 951-972.

McCracken, G. (1988), The Long Interview, London: Sage Publications Ltd.

Nandan, S. (2005), “An exploration of the brand identity-brand image linkage: A communications perspective", Journal of Brand Management, Vol. 12 No. 4, pp. 264278.

Needham, C. and Smith, G. (2015), "Introduction: Political Branding", Journal of Political Marketing, Vol. 14 No. 1-2, pp. 1-6.

Needham, C. (2005), "Brand Leaders: Clinton, Blair and the Limitations of the Permanent Campaign”, Political Studies Banner, Vol. 53 No. 2, pp. 343-361.

Nord, L.W. and Stromback, J. (2009), "Marketing with a Feeling: The Brand New Party Junilistan on the Swedish European Parliamentary Elections 2004", Journal of Political Marketing, Vol. 8 No. 1, pp. 35-45.

O’Cass, A. and Voola, R. (2011), "Explications of political market orientation and political brand orientation using the resource-based view of the political party", Journal of Marketing Management, Vol. 27 No. 5-6, pp. 627-645.

O’Shaughnessy, N. J. and Baines, P. R. (2009), “Selling Terror: The symbolization and positioning of Jihad”, Journal of Marketing Theory, Vol. 9 No. 2, 227-241.

Peng, N. and Hackley, C. (2009), “Are Voters, Consumers? A qualitative exploration of the voter-consumer analogy in political marketing", Qualitative Market Research: An International Journal, Vol. 12 No. 2, pp. 171-186.

Pettigrew, S. and Charters, S. (2008), “Tasting as a projective techniques”, Qualitative Market Research: An International Journal, Vol. 11 No. 3, pp. 331-343.

Phipps, M. Brace-Govan, J. and Jevons, C. (2010), "The duality of political brand equity”, European Journal of Marketing, Vol. 44 No. 3/4, pp. 496-514.

Pich, C. and Dean, D. (2015), "Qualitative projective techniques in political brand image research from the perspective of young adults", Qualitative Market Research: An International Journal, Vol. 18 No. 1, pp. 1-36.

Radice, G. (1992), Southern Comfort, Fabian Society Pamphlet. 
Radice, G. (1993), More Southern Comfort, Fabian Society Pamphlet.

Radice, G. (1994), Any Southern Comfort, Fabian Society Pamphlet.

Robinson, C, (2010), "Political advertising and the demonstration of market orientation", European Journal of Marketing, Vol.44 No. 3-4, pp. 451-460.

Ross, T. (2015), Why the Tories Won: The Inside Story of the 2015 Election. Biteback Publishing Ltd, London, England.

Rubin, H.J. and Rubin, I.S. (1995), Qualitative Interviewing: The Art of Hearing Data, London: Sage Publications Ltd.

Saunders, M. Lewis, P. and Thornhill, A. (2012), Research Methods for Business Students, Essex: Pearson Professional Ltd.

Scammell, M. (2015), "Politics and Image: The Conceptual Value of Branding", Journal of Political Marketing, Vol. 14 No. 1-2, pp. 7-18.

Sloam, J. and Henn, M. (2018), Youthquake 2017: the rise of young cosmopolitans in Britain. Palgrave studies in young people and politics. Basingstoke: Palgrave Macmillan. ISBN 9783319974682.

Smith, G. (2009), "Conceptualising and Testing Brand Personality in British Politics", Journal of Political Marketing, Vol. 8 No. 3, pp. 209-232.

Smith, G. (2008), "Politically Significant Events and Their Effect on the Image of Political Parties", Journal of Political Marketing, Vol. 4 No. 2-3, pp. 91-114.

Smith, G. (2005), "Positioning Political Parties: The 2005 UK General Election", Journal of Marketing Management, Vol. 21 No. 4, pp. 1135-1149.

Smith, G. and French, A. (2009), "The political brand: A consumer perspective", Marketing Theory, Vol. 9 No. 2, pp. 209-226.

Smith, G. and Saunders, J. (1990), "The application of marketing to British politics", Journal of Marketing Management, Vol. 5 No. 3, pp. 295-306.

Speed, R. Butler, P. and Collins, N. (2015), "Human branding in political marketing: Applying contemporary branding thoughts to political parties and their leaders", Journal of Political Marketing, Vol. 12 No. 2-3, DOI: 10.1275/15333457.2013.781278.

Strauss, A. and Corbin, J. (1998), Basics of Qualitative Research: Techniques and Procedures for Developing Grounded Theory (2nd ed.). London: Sage.

Thompson, C. J. Rindfleisch, A. and Arsel, Z. (2006), "Emotional Branding and the Strategic Value of the Doppelgänger Brand Image", Journal of Marketing, Vol. 70 No. 1, pp. 50-64. 
Trochim, W. and Donnelly, J. (2007), The Research Methods Knowledge Base, USA: Thomson Corporation.

Van Manen, M. (2014), Phenomenology of Practice: Meaning-Giving Methods in Phenomenological Research and Writing. London Sage.

Warren, C.A.B. and Karner, T.X. (2005), Discovering Qualitative Methods: Field Research, Interviews and Analysis, California: Roxbury Publishing Company.

Welch, C. Piekkari, R. Plakoyiannaki, E. and Paavilainen-Mantymaki, E. (2011), "Theorising from case studies: Towards a pluralist future for international business research", Journal of International Business Studies, Vol. 42 No.5, pp. 740-762.

White, J. and de Chernatony, L. (2002), "New Labour: A Study of the Creation, Development and Demise of a Political Brand", Journal of Political Marketing; Vol. 1 No. 2/3, pp. 45-52.

Wring, D. (2002), "Conceptualising Political Marketing: A Framework for ElectionCampaign Analysis", In: O'Shaughnessy, N.J. and Henneberg, S.C.M. (ed), The Idea of Political Marketing, Praeger Publishers, Westport, pp.171-185.

Yin, R. K, (2009), Case Study Research, (4th ed.) Thousand Oaks, CA: Sage.

Zikmund, W.G. (2003) Business Research Methods, USA: Thomson Learning SouthWestern. 
Reviewers Comments

Regional editor comments

Thank you for submitting your revision. As you will see the same knowledgeable reviewers and $A E$ have evaluated your revised manuscript. The $A E$ and $R 2$ are satisfied that you have addressed their concerns. R1 still have some significant concerns. All agree that you have moved the script significantly forward since the last round. I offer you the following guidance in further revising your manuscript.

1) I am not convinced that you need the 'exploratory' descriptor it devalues your qualitative work. Focus instead on positively justifying your method - be confident in your approach. I would take the exploratory terms out. Also, is your study defensible as a case study? Please address R1's concerns in this regard with to this point, which could be done by strengthening your justification for your approach.

2) Strengthen your introduction by offering a more compelling argument for your framework and subsequently strengthen your literature review following so that a reader fully understands the framework that you are using as a basis (please see R1 on these points).

3) Remember that you are writing for a wide and diverse audience and $\mathrm{R} 1$ raises some important communication issues in this respect. You should provide more detail regarding your
Action taken

Thank you for taking the time to review our revised paper. We appreciate all the time, constructive feedback and support through the submission and review process. By responding to your comments, we believe this has improved the paper in terms of focus, clarity and contribution. We respond to each comment below and highlight how we have improved the paper and on what page this is.

We agree with your comment on the 'exploratory' descriptor and case study approach and we have removed this from the paper. We have expanded the justification and detail of our method and methodology. We did adopt an interpretive approach but as you say we needed to be braver to state this. Therefore we have provided detail with a justification for each stage of the research design. In addition, we provide detail in terms of the length of each interview, focus group, the sampling framework adopted and more insight into how we recruited our sample. Overall, this sharpens and strengthens our methodology.

We have strengthened our introduction. critically evaluating the political branding literature, particularly the issue of identity and image which emphasized the challenges of trying to characterize these as relational but distinct when in reality it is more complex. This highlights a gap in the body of knowledge where making brand meaning is a complex process and ongoing process where the internal party members and the electorate co-create the brand message. The introduction finishes with reference to calls for future research and the aim of the study, which in turn strengthens the argument for the study. We have reflected on this and positioned the paper for a wider and diverse audience. This is evident throughout the findings-discussion [pages 15-29] section and in the conclusion [page 29-31] section for

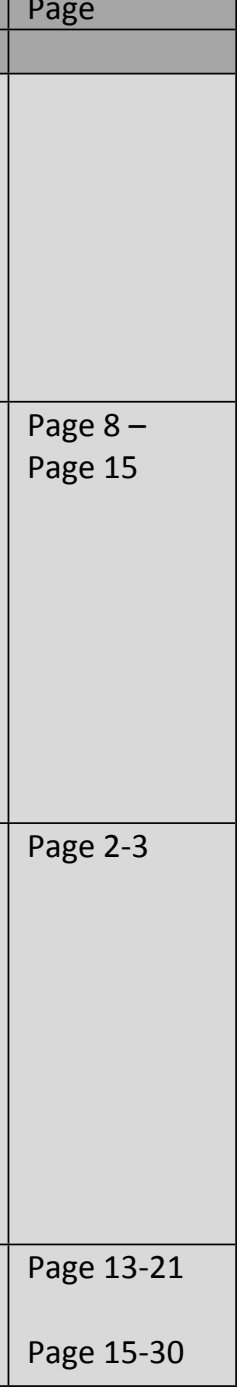




\begin{tabular}{|c|c|}
\hline $\begin{array}{l}\text { analysis especially with respect to how the framework informed } \\
\text { your analysis and vice versa. } \mathrm{R} 1 \text { also asks for some more details } \\
\text { about the method - which should be supplied. }\end{array}$ & $\begin{array}{l}\text { researchers/practitioners within and outside political branding and } \\
\text { across-beyond Europe. We have also provided more detail in terms of } \\
\text { the analysis and key findings [pages } 15-21 \text { ] and demonstrated how the } \\
\text { framework was developed from our analysis, which underpins our } \\
\text { contribution. More detail has been provided about the methods used } \\
\text { [as outlined in point one]. }\end{array}$ \\
\hline \multicolumn{2}{|l|}{ Reviewer 1 comments } \\
\hline $\begin{array}{l}\text { I've been asked to review the revised version of a manuscript } \\
\text { that I had previously reviewed. The stated purpose of this } \\
\text { manuscript is to explore the dynamics between brand identity } \\
\text { and brand image in the context of political branding and } \\
\text { marketing. The paper reports the findings of an exploratory } \\
\text { qualitative case study of the Conservative Party in the UK with } \\
\text { fieldwork carried out in the months before the } 2015 \text { general } \\
\text { election. } \\
\text { I am happy to say that the revised version of this submission is } \\
\text { much improved, in particular, in terms of the literature review } \\
\text { and the intended purpose. It is also now more clearly positioned } \\
\text { within a disciplinary context and subject area (i.e. political } \\
\text { branding). In addition, the presentation of findings is more } \\
\text { structured and better presented. Having said this, I'm still } \\
\text { struggling to see an original enough theoretical contribution } \\
\text { clearly derived from the qualitative exploratory case study } \\
\text { undertaken. I am also now even less convinced of the } \\
\text { methodological merits of this study, I am afraid. }\end{array}$ & $\begin{array}{l}\text { Thank you for reviewing our paper for the second time. We appreciate } \\
\text { your time, support and constructive feedback. We believe your } \\
\text { direction has strengthened the core proposition of the paper and } \\
\text { improved significant sections of the paper such as methodology, } \\
\text { findings, discussion and conclusions. In addition, we are pleased to hear } \\
\text { you think there was improvement with the literature review, position } \\
\text { and intended purpose. In addition, we are happy to hear you could see } \\
\text { improvement in terms of the structure and presentation of the findings } \\
\text { section. }\end{array}$ \\
\hline $\begin{array}{l}\text { Instead of the previous conceptual framing the author(s) have } \\
\text { now chosen to introduce a different conceptual framework } \\
\text { derived from existing models (i.e. Kapferer and Bosch et al.). } \\
\text { Yet, the paper in its current form still fails to communicate } \\
\text { clearly how the conducted fieldwork empirically and analytically }\end{array}$ & $\begin{array}{l}\text { We have removed reference to exploratory research and repositioned } \\
\text { the paper away from a case study approach. This strengthens the } \\
\text { methodology section. Given your comments about the original } \\
\text { contribution and also how we built theory from our data, addressed } \\
\text { your concerns by firstly going back to the branding literature and }\end{array}$ \\
\hline
\end{tabular}


justifies such a move nor does the literature review sufficiently develop the new framework in a meaningful way; apart from some generic arguments re the need for consistency between brand identity and image and the apparent lack of models that integrate both dimensions and the fact that it has been derived from Kapferer and Bosch et al. This might be highly interesting and very useful from an applied point-of-view but it does not in itself constitute a valid theoretical contribution to a scholarly journal, IMO.

This is because the way the study is now reported in the revised paper gives the impression as if the combination of the two existing conceptual models was rather arbitrary or ad-hoc after the fieldwork had been conducted; as if the empirical materials where simply retroactively matched to this framework rather than the framework resulting from the empirical inquiry (or an analytic back and forth between empirical data and extant literature). This is highly problematic, not only conceptually but also from a methodological point of view.

The strength of qualitative and interpretive case studies and their usual methodological purpose is to explore and develop new theoretical possibilities that analytically emerge from the rich data generated, triangulated and synthesised into a new conceptual understanding of the lifeworld of actors in situ. Even if one assumes that the use of preconceived models is permissible, the manuscript does not show how the coding and thematic analysis of the interviews and focus group recordings is linked or was informed by the new framework.

This leads me to some methodological shortcomings in terms of how the work is presented in the revised manuscript. The interpretive aspect of the study is lost due to the use of the critically evaluated the concepts of identity and image. Following on from this we then re analysed the data and moved away from trying to make the data fit into the identity image framework. This was not how we conducted the research so thank you for making us consider theoretical alternatives, which is a little more risky than supporting existing research. Following on from this we addressed your later comment and have revised the conceptual framework as part of our discussion-contribution. Therefore, the theoretical framework was developed from inductive themes from the interviews and focus groups rather than making the themes fit the original model in the literature review. Therefore, the original conceptual framework has been removed and our revised theoretical framework developed from our findings is presented and discussed from page 23 to page 29. This highlights our theoretical contribution to the body of knowledge. This is summarized in the conclusion section pages 29-31.

In terms of addressing your comments in regards to the methodological shortcomings, we have removed any reference to 'case studies' and used the Conservative Party to 'contextualize' the study. We agree, a 
conceptual framework. The way the findings are presented, while more structured and clearer, the focus is too much on matching the data to the different dimensions of the (preconceived) model rather than engaging with and developing understanding of human experiences. To reiterate, there is inductive theory building taking place as claimed by the author(s) in their methodology section.

Moreover, case studies usually require some form of triangulation (method, data, sources etc.) and corroboration which is not evident either. At the moment it seems two separate pre-existing studies - one interview study and one focus group study - are put together and the author(s) seek to fudge the fact that there is a lack of prior conceptual and methodological coherence and consistency within a clearly defined conceptual case (and not just an empirical one). I am not saying this is the case, it is just how it comes across in the manuscript.

In addition, the sampling of participants is justified from a pragmatic or empirical perspective (e.g. why the demographic of the chosen participants is relevant for the Conservative Party) but it is not articulated from a conceptual and theoretical point of view. This requires further work.

I also suggest you include the actual themes and codes that emerged from you data analysis (as suggested in your methodology section) and how they informed your conceptual deliberations. This is currently missing from the manuscript and undermines the trustworthiness of your study. case study approach is not suitable for our project. We had used an inductive, interpretive approach to the data collection and analysis of our findings, which in turn developed our theoretical framework outlined in the discussion section. We have provided detailed explanation for the methodological approach. We also reflected on how we illustrated our findings and analysis. For example, we revisited the findings from the interviews and focus group discussions and ensured we followed an inductive approach to thematic analysis outlined on pages 14-15. We illustrated the analytical process via a datastructure approach put forward by Gioia et al., (2012) - pages 14-21. The first column represents key points raised by the participants. The second column represents sub-themes assigned by the researchers based on the key points raised by the participants whereas the third column represents the over-arching themes. This in turn grounded the development of our theoretical framework entitled the 'brand alignment framework' illustrated on page 26 [figure 4] and outlined on page 27 [table 4]. Therefore, the brand alignment framework forms the basis of our contribution to theory and this has implications for theory/practice outlined in the conclusion section. We hope the clarification has improved the focus of our study.

We have included the sampling framework for stage one [interviews]

Pages 8-14 and stage two [focus group discussions] and linked this to the pragmatic justification for our sample. Evident on pages 8-14.

We have now illustrated more clearly the themes and codes that emerged during the analysis.

Furthermore that enabled us to reconsider the conceptual framework and how they contributed towards a more original model that also is able to be operationalized.

\section{Pages 17-21 \\ Page 26-27}




\begin{tabular}{|c|c|c|}
\hline & $\begin{array}{l}\text { We also revisited the methodological literature and utlised the work of } \\
\text { Gioia et al. (2012) to improve the transparency of our data collection } \\
\text { and analysis }\end{array}$ & \\
\hline $\begin{array}{l}\text { I would also like to see more technical details in the } \\
\text { methodology section in terms of duration of each interview } \\
\text { (focus group), the word count of the transcripts and so on. I also } \\
\text { suggest you use aliases for the interviewees rather than the } \\
\text { codes currently included. }\end{array}$ & $\begin{array}{l}\text { We agree - we have added more technical details about the } \\
\text { methodology for example pages } 8-15 \text {. We have removed reference } \\
\text { to the 'case study approach' and used aliases for the interviewees and } \\
\text { participants in the focus groups. We have also added additional detail } \\
\text { such as the length of interviews and focus groups and also the word } \\
\text { count for the transcripts. }\end{array}$ & Pages 8-15 \\
\hline $\begin{array}{l}\text { In light of the above, you have two options really. Either you get } \\
\text { rid of any preconceived or pre-existing conceptual model (even } \\
\text { as a 'novel' combination) and focus on the categories and } \\
\text { themes emerging from the data. In other words, with a truly } \\
\text { interpretive spirit let the rich qualitative data guide you first and } \\
\text { foremost. Otherwise, you need to clearly show the link between } \\
\text { the conceptual framework, the empirical work and the data } \\
\text { analysis that you did (not just matching relevant data to the } \\
\text { dimensions of the model); also clearly identifying the coding } \\
\text { system derived from the conceptual model, with a clear } \\
\text { separation between in vivo and a priori codes and so on. In the } \\
\text { latter case you also needed to conceptually justify the new } \\
\text { framework much more forcefully up front and link it to the } \\
\text { choice and sampling of the case and participants. }\end{array}$ & $\begin{array}{l}\text { Based on the two options you put forward, we decided to position the } \\
\text { paper via recommendation one - 'Either you get rid of any preconceived } \\
\text { or pre-existing conceptual model (even as a 'novel' combination) and } \\
\text { focus on the categories and themes emerging from the data. In other } \\
\text { words, with a truly interpretive spirit let the rich qualitative data guide } \\
\text { you first and foremost'. Again, we revisited the findings from the } \\
\text { interviews and focus group discussions and ensured we followed an } \\
\text { inductive approach to thematic analysis outlined on pages } 14-15 \text {. We } \\
\text { illustrated the analytical process via a data-structure approach put } \\
\text { forward by Gioia et al., (2012) - pages } 14-21 \text {. The first column } \\
\text { represents key points raised by the participants. The second column } \\
\text { represents sub-themes assigned by the researchers based on the key } \\
\text { points raised by the participants whereas the third column represents } \\
\text { the over-arching themes. This in turn grounded the development of our } \\
\text { theoretical framework entitled the 'brand alignment framework' } \\
\text { illustrated on page } 26 \text { [figure } 4 \text { ] and outlined on page } 27 \text { [table } 4 \text { ]. } \\
\text { Therefore the brand alignment framework forms the basis of our } \\
\text { contribution to theory and this has implications for theory/practice } \\
\text { outlined in the conclusion section. }\end{array}$ & Pages $14-20$ \\
\hline $\begin{array}{l}\text { Finally, I suggest you clearly separate theoretical and practical } \\
\text { implications in your discussion. The theoretical implications need }\end{array}$ & $\begin{array}{l}\text { We take on board your suggestions to separate the theoretical and } \\
\text { practical implications of our study. This is discussed on pages } 23-29 \text { and }\end{array}$ & $\begin{array}{l}23-29 \text { and } \\
29-31\end{array}$ \\
\hline
\end{tabular}


to be more close linked to substantive conceptual and theoretical issues currently or previously debated in the academic literature (currently they seem to be rather generic and broad).

Your manuscript has many strengths (especially the applied and practical aspects of it) but I am not convinced that it makes an original and novel theoretical contribution at this stage. In light of the previous version of this, I suggest a rejection and encourage you to take some time for redeveloping your paper first before any resubmission. I am sorry that my comments may read rather harsh but I hope they will help you to further improve your work (with a very interesting empirical setting in principle).

Reviewer 2 comments summarized on pages 29-31. For example, we discuss how our research and framework addresses the identified gap in the body of knowledge. This is followed by the practical implications of our research and also an agenda for future research.

Overall, we are happy that you can see the many strengths in our paper. We have developed the originality and theoretical contribution of the paper. This is summarized in the conclusion section pages 27-31. Please do not be sorry for your comments. We saw your comments not as harsh but informative, constructive and helpful. We are very grateful to your time and believe your comments have helped repackage and reposition the paper, which in turn strengthens our contribution, originality and impact. For example as outlined in the conclusion section 'The aims of this research were to respond to Baines et al.'s (2014) call for research devoted to exploring how political actors present their brand and how this is understood by the electorate. Indeed, a holistic approach revealed how political actors created and managed political brand meaning and illustrated how young voters made sense of the brand (Baines et al. 2014; Needham and Smith, 2015; O'Cass and Voola, 2011). As there are limited, operational mechanisms designed to monitor how a political brands are positioned (Baines et al. 2014; O'Shaughnessy and Baines 2009; Smith 2005; Smith and Saunders 1990), we developed the brand alignment framework, a theoretical model that can identify anomalies between political identity and image. Further, the Conservative Party served to contextualise this study'. Thank you once again - we believe your comments have helped improve our work.

The authors have done a great job addressing the concerns and issues raised in the previous review. 
There is practical and applied benefit to the work, the authors have responded to my suggestions for improvement and the article will be highly valuable and well received in the political marketing field.

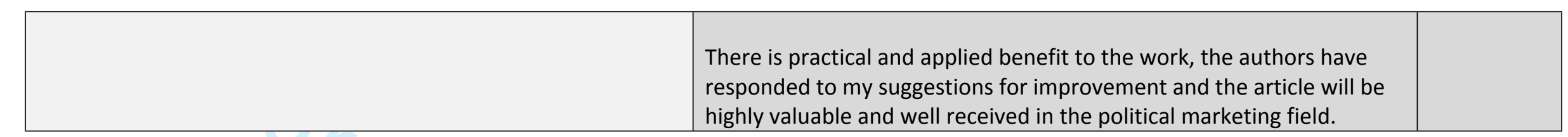

